[2]の水和反応に拉いては, 転化率も小さく, 弪生成物は[6] で, 少量の[8]抽よび[11]が得られた炕すきないこのこと から，〔2〕は反応の中間体としては，あまり大きな答少はない

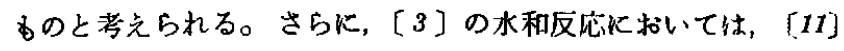
拉よび〔て〕が生成したが，〔4〕はほとんど生成しないことがわ
かった 18 。

以上の結果から，水和反応は，図 1 に示した径路で進さるのと 考えられる。

18）〔11]の IR 120 による反応では，1,8-テルビンは少量得 られるのみで，膂化水素類が生成した。

\title{
The Hydration Reaction of Myrcene by the Cation Exchange Resin ${ }^{\dagger}$
}

\author{
Juntaro TANaka, Takao Katagiri, Kunihiko TAKabe \\ and Osamu NaKachI \\ Department of Synthetic Chemistry, Faculty of Engineering, \\ Shizuoka University; Hamamatsu-shi, Japan
}

The direct hydration of myrcene[1] by the cation exchange resin(Amberlite IR 120) was studied. The hydrated products consisted of myrcenol[9], 1,8-cineol[4] and 2,6-dimethyl-5,7octadien-2-ol[10] along with other alcohols and unsaturated cyclic hydrocarbons(Table 1). From the results the reaction scheme is discussed.

$\dagger$ The Reactions of Terpenoids. II.

正

鴻巣久雄、益子洋一郎, 佐藤正人, 日化, 1972, 48；

右段, Table 1 の右檯

$$
\text { " } 1152 \text {; }
$$

左段, 上から 5 行目

鸿梁久雄, 佐藤正人，益子洋一郎, 日化, 1972, 55； 左段, 上から 14 行目

$$
\text { " }
$$

右段, 上から 7 行目

$"$

左段，Fig.7 の・印説明

"

Table 4 の右撋

"1

英文要旨本文 $9 \sim 10$ 行

金沢孝文，梅垣高士，日化，1972，335；和文概要 6 行目

坂井納司，田中 昭，古贺 元，J.-P. Anselme，日仁，92， 1065(1971)；左段, 膟注 *1

\section{$"$}

1074(1971)；図式 14の[33]

58 ;

58 ;

59 ;

"
㒥

正

for population

測定侐の変動係数

4. 1

Lーリシン

$$
+1155.7 y^{2}(\quad " \quad 3 \sim 9)
$$

Coefficient

•

10 行目の「0.2 200 of $\mathrm{NaCl}$; 」 を9行目のはじめに移す

錕形成

University of Massachusetts at Boston<smiles></smiles>

謂

fo rpopulation

測定値の HV 变動係数

4. 1

Lーทシス

$+1155.7 y^{2} \quad$ " $\left.3 \sim 9\right)$

Coeffient

錯形式

University of Massachusetts

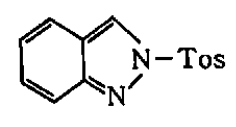

(33) 
山下那都樹, 清田 徽, 吉原正邦, 龍崔俊寿, 工化, 74, $2160(1971)$; 右段, 図 6 の表㬈 " "

2162(1971)；右䛋, 上から 10 行目

2162(1971)；右段, 上から 15 行目 桶田秀雄, 山神喜三郎, 榎 吉二, 谷 敏行, 工化, 74, 2489(1971)；左段，図 11 をつきのように訂正する。
初期重合速度

初期酸重合速度

$$
\begin{gathered}
\text { 鎖状アセタールよりb環状フセ } \\
\text { タールの方が }
\end{gathered}
$$

重要になっている

重合によっている

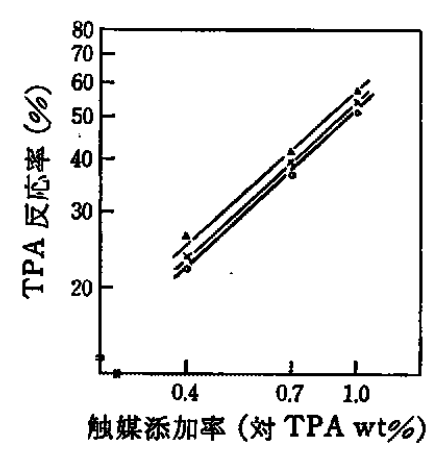

図 11 無溶媒法における触媒添加率 と反応速度との関係

蝶 : トリヘーブロビルフミン

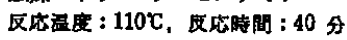
EO/TPA $0: 4, x: 6, \Delta: 8$
鎖状フセタールの方が 